\title{
READERS
insight
}

Journal of Research in Psychology

www.readersinsight.net/jrp

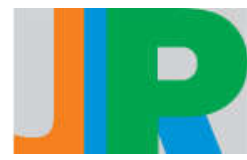

\section{Influence of Organizational Conflict Management and Procedural Justice on Employee Performance in Academia of Pakistan}

\author{
Aqsa Zahid ${ }^{1}$, Mashal Zahra ${ }^{1}$, Mehwish Amjad', Rimsha Mukhtar ${ }^{1}$, Muhammad Hamza', Razzaq \\ Athar $^{1^{*}}$
}

${ }^{1}$ Pir Mehr Ali Shah Arid Agriculture University, Rawalpindi, Pakistan.

\begin{abstract}
*Corresponding author: razzaq_athar@yahoo.com

Abstract
We conduct this research to investigate the way conflict management and procedural justice can affect
employee performance in academia of Pakistan. We used the quantitative method to conduct our research,
we take a sample size of 322 employees $(n=322)$ who work at different positions in universities. We used
SPSS technique to analyze our data, use different tests regression, correlation and reliabilities. The results
of correlation show a significant relationship between all of our three variables. This shows that for
organizational performance, both conflict management strategies adopted by managers and perception of
procedural justice are important..
\end{abstract}

ARTICLE INFORMATION

Received: $09^{\text {th }}$-May-2019

Revised: $10^{\text {th }}-$ Jul-2019

Accepted: $3^{\text {rd }}$-Aug-2019

Keywords: conflict management, employee performance, procedural justice

\section{INTRODUCTION}

The conflicts related with work life are all time mostly high and they are growing for the past 30 years. Organizations have introduced different types of initiatives that have produced different results, in order to enable employees to better manage workplace conflicts. It is reported in the literature that there existed a correlation among conflict, conflict management techniques, procedure justice and employee performance. Efficient conflict management techniques yield positive results in the end.

Employee's performance is a multi-component concept and one can elaborate the procedure and area of performance, that is behavioral engagement of an expected result. The behavior describes here the action of people to full fill a task, whereas the term result and consequences situations about the results related to job behaviors of each employee (Pradhan \& Jena, 2017). Job performance compares of job external attitudes that includes job duties allot as a part of task knowledge, job skills and task habits. Job performance states how well employee performance tasks, duties and responsibilities of his or her job (Campbell, McCloy, Oppler, \& Sager, 1993). Employee performance is higher in happy and satisfied employees and the management fined it easy to motivate higher performance to attain firm's goals and targets(Zelenski, Murphy, \& Jenkins, 2008).

An organizational factor that can influence the performance is conflict. Mullins (2015) considers conflict as behavior designed to impede the attainment of the objectives of other person. According to this author, conflict is based on thr incompatibility of goals and arises from opposing behaviors. It can be viewed separately, in organizations or at the level of organization

In Ilesanmi (2017) words, conflicts may occur over a variety of organizational experiences, such as inconsistent objectives, differing beliefs and shared assets, philosophies and disputes. Conflict is a viewpoint, so it begins when a person thinks that someone else might hinder their efforts. Conflict could occur as a consequence of the employer's desire to maximize gain, while due to the employer's search for profit maximization while employee representatives are committed to ensuring a continuously enhanced living condition for the conflict of their member. When one think is important for two parties and they seems to think that their interests are endangered by other party, conflict occurs (Abiodun, 2014).

Organizational change is another cause of conflict. It's natural to resist change and comes from once established habit, few of the unknown, conformity with the usual anticipated behavior, misunderstanding of change consequences and differences between individuals. It could lead to dispute or even crises, he said, unless it is well managed. Unless, it is well managed, he said, it could lead to conflict or even crises. Other causes of organizational conflict are competition for scarce resources, congruence status, win-win situations, win-lose situations, the need for change, unclear laws and communication problems among others (Armstrong, 2010).

The difference between functional conflict and dysfunctional conflict depend upon whether the organizations interests are served. Some kinds of conflict support the objectives of the organization and enhance efficiency; these are functional, constructive types of conflict, 
they aid the organization. Functional conflict is commonly defined as a corporate or constructive dispute leadership circle., On the other side, dysfunctional conflicts are the kind of dispute that hamper organizational efficiency (Robbins \& Judge, 2007).

Although corporate research on teams and conflict have exceeded somewhat independently, recent studies have enlightened the critical role of disagreement in groups. Groups should address, among other problems, efficient and fair jobs and rewards allocation, social loafing, and the perfect method to accomplish their objectives (Hackman, 1990). Groups give an interpersonal context in which disagreements take place and efforts are made to handle them. Previously in hierarchical organizations, employees are anticipated to make their managers and supervisors aware of issues and conflicts and abide by their decisions (Wageman, 1995). In organizations that prefer groups, particularly self-management and different types of empowered groups, employees are supposed to solve issues and disagreements themselves (Cohen \& Ledford Jr, 1994). Selfmanagement teams theorists have suggested that staffs are better designated to correct them as they are nearer to the source of mistakes and variances in management. They are educated in quality management and provided the ability to stop or accelerate efficiency. Their involvement in resolving these disputes is expected to boost "ownership" of problems and greater dedication to apply their alternatives resulting in enhanced efficiency, quality of product, and work life (Pasmore, Francis, Haldeman, \& Shani, 1982).

Conflict among employees has significant effects on motivation (De Dreu \& Weingart, 2003). Skills of superiors also play an important role in managing employee performance because enhancing employee's performance is the main concern of all the organization (Nur Shafini et al., 2016).

H1: Conflict management will be positively related to employee performance.

Organizational Justice is the domain which is responsible for the equal treatment of employee. It is a applied mindset of indiscriminate behavior in company (Lind \& Tyler, 1988; Sheppard, Lewicki, \& Minton, 1992). As obvious, the intriguers took this ideology from already present "social-psychological" literature on equal treatment. Bies echoed this in his interview, "justice originally came out of social psychology'. It is inevitable arena of further intrigue because of its trickledown effect in the growth of an organization. Organization justice researcher have unanimous agreement that fairness is plausibly bifurcated in two parts (although other frameworks may also be reasonable. It has two categories namely: distributive and procedural justice. Procedural fairness helpful to improve employee performance which increases organization performance. It has been proved by studies that Procedural Justice have ripple effects in improving performance of many sections (Luria \& Yagil, 2008; Simons \& Roberson, 2003). Procedural justice advances firm environment and employee attitude toward their work commitment and motivated for their performance (Zapata-Phelan, Colquitt, Scott, \& Livingston, 2009). Procedural justice helpful to build strong relation between employee and firm put their efforts for the completion of organizational goal (Tyler \& Blader, 2003).

Therefore, it is hypothesized that:

H2: organizational procedural justice will be positively related to employee performance
The research framework is shown in fig 1.

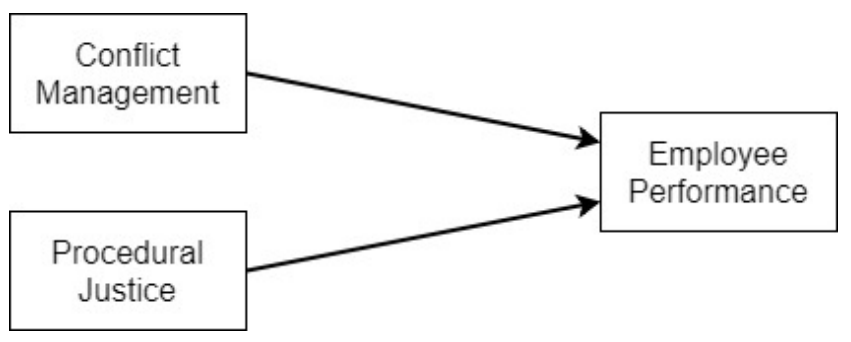

Fig. 1: Research Framework

\section{MEASURES}

\section{Conflict Management:}

We measured conflict management by using a 21-items established by Gaumer Erickson and Noonan (2018). This measure estimated the conflict management; we adapt this scale according to our study. Sample item includes "This firm strives to kept its statements regarding to employees, and make efforts to manage conflicts constructively".

\section{Procedural Justice:}

We measure procedural justice by using 9-items established by Jaworski and Kohli (1991).This study indicate that organization commitment tends to be more highly associated with procedural justice. "At all times, I ready to help my colleagues who have burden of work ", "I do help those persons who call for".

\section{Employee Performance:}

We measured employee performance by using scale adopted from Wiedower (2002). This was a five items include "I try to find out unique and beneficial ways to settle down serious issues", "I look for fresh way of processes of relationship management communication and corporate vision with job performance, employee commitment".

\section{SAMPLE AND PROCEDURE}

To conduct our study, we used quantitative method. The purpose of this technique is to assemble and advance numerical data examination model in order to evaluate our hypothesis. For this purpose of our study, we have selected educational sector. Most of the employees in these universities are employed as Full Professors, Associate Professors, Assistant Professors, visiting faculty, Assistant Directors, Directors and administration. We used purposive sampling technique for our study; the total number of participants in our research is 322 . Table 1 displays the demographics distribution of the sample.

Table 1. demographics table

\begin{tabular}{lll}
\hline \multicolumn{1}{c}{ Demographics } & Frequency & Percentage \\
\hline Gender & & \\
Male & 172 & 53.4 \\
Female & 105 & 32.6 \\
No response & 45 & 14 \\
Age & & \\
$20-30$ & 47 & 14.6
\end{tabular}

Copyright (C) 2019 Authors. This is an open access article distributed under the Creative Commons Attribution License, which permits unrestricted use, distribution, and reproduction in any medium, provided the original work is properly cited. 


\begin{tabular}{lll}
\hline \multicolumn{1}{c}{ Demographics } & Frequency & Percentage \\
\hline $30-40$ & 87 & 27 \\
$40-50$ & 93 & 28.9 \\
$50+$ & 76 & 23.6 \\
No response & 19 & 5.9 \\
Qualification & & \\
Diploma & 49 & 15.2 \\
Bachelor & 60 & 18.6 \\
Master & 72 & 22.4 \\
MS & 62 & 19.3 \\
PhD & 79 & 24.5 \\
Departments & & \\
Accounting & 55 & 17.1 \\
Software & 101 & 31.4 \\
Sales and arketing & 73 & 22.7 \\
HRM & 56 & 17.4 \\
Others & 37 & 11.5 \\
Experience & & \\
1 to 5 & 35 & 10.9 \\
6 to 10 & 127 & 39.4 \\
10 to 15 & 124 & 38.5 \\
16 to 20 & 17 & 5.3 \\
20+ & 19 & 5.9 \\
\hline
\end{tabular}

\section{CORRELATION}

The results of our all variables is strong or large correlation between them, because all our values are greater than 0.50 and significant.

Table 2: Correlations

\begin{tabular}{|c|c|c|c|}
\hline & $\mathbf{C M}$ & EP & PJ \\
\hline$\overline{\mathrm{CM}}$ & 1 & $.680^{* *}$ & $.627^{* *}$ \\
\hline EP & . & 1 & $.718^{* *}$ \\
\hline
\end{tabular}

\section{REGRESSION}

Table 3 shows the regression results. It can be seen that the model was a good fit since F value was significant. The R2 and adjusted R2 value shows that both the variables explain $46 \%$ variance in job performance. One-unit change in conflict management increase job performance by 0.62 units and one unit increase in procedural justice increase job performance by 0.70 units.

Table 3: Regression results

\begin{tabular}{ll}
\hline Predictor & Beta \\
\hline $\mathrm{CM}$ & $0.62^{* * *}$ \\
$\mathrm{PJ}$ & $0.70^{* * *}$ \\
$\mathrm{R}^{2}$ & 0.463 \\
Adjusted $\mathrm{R}^{2}$ & 0.461 \\
$\mathrm{~F}$ & 275.8 \\
\hline Dependent variable $=$ & Employee performance \\
$* * \mathrm{P}<0.01, * * * \mathrm{P}<0.001$ &
\end{tabular}

\section{DISCUSSION}

Conflict management and maintaining employee performance are very important things in any organization. To survive in such a competitive environment, managing conflicts at workplace plays an important role in making employees performance outstanding. An easier way to manage conflicts at workplace is to involve equality, fairness in procedures and avoid biasness. Managers need to design workplace when employees give their best. Conflict management's importance is undeniable in this too. A correlation exists between conflict management and employee performance effect size of the which is (0.680), CM and EP have strong relationship, when employees observed that everyone is treated fairly and the conflicts are managed by win- win situations, they show their positive attitude towards performance, that's why organization need to focus on how they can manage the conflicts among employees.

Our research points out that when conflicts among employees are managed constructively among employees, it leads to increase in employee's performance and procedural justice can strengthen this relationship. If the conflicts are not managed effectively among employees and procedures of organization are not fair, the employees may not actively participate activates and perform well in the organization, they may reduce their efforts and decrease their performance. This study provides evidence that minimum conflicts among employees and high degree of procedural fairness are positively connected to higher level of effectiveness in employee's performance. So, it is necessary to consider those variables which affect the performances of workers because these factors lead to expansion of organization. In addition our results were also in accordance with social Exchange Theory to anticipate relationship between procedural justice and employee performance (Cropanzano, Prehar, \& Chen, 2002; Masterson, Lewis, Goldman, \& Taylor, 2000). This theory sees organization as forum for deep- rooted, interchangeable social dealings among employees and their superiors. Researcher said that conflicts also have constructive results (De Drue \& Gelfand, 2008; Jehn \& Mannix, 2001; Tjosvold, 2008).

\section{FUTURE RECOMMENDATION}

Based on our study results, the following suggestions are provided. We have done this research in academic sector. This research can be further conducted in any other sector, in any other country, or in any other culture. Further research can be done with any other type of organizational justice. We have undergone research to view the impact of conflict management on performance. It can be carried out with any other variable. All faculty members should be made aware of the beneficial use in their departments of conflict management. For the professors in general and administrators in specific, conflict management training programs should be intended. Conflict management strategies should be taught to the faculty. This will certainly increase their efficiency and minimize the conflict's lethal elements.

\section{REFERENCES}

Abiodun, A. R. (2014). Organizational conflicts: Causes, effects and remedies. International Journal of Academic Research in Economics and Management Sciences, 3(6), 118.

Armstrong, M. (2010). Armstrong's essential human resource management practice: A guide to people management: Kogan Page Publishers.

Campbell, J. P., McCloy, R. A., Oppler, S. H., \& Sager, C. E. (1993). A theory of performance. Personnel selection in organizations, 3570, 35-70.

Cohen, S. G., \& Ledford Jr, G. E. (1994). The effectiveness of self-managing teams: A quasi-experiment. Human Relations, 47(1), 13-43.

Cropanzano, R., Prehar, C. A., \& Chen, P. Y. (2002). Using social exchange theory to distinguish procedural from interactional justice. Group \& Organization Management, 27(3), 324-351.

De Dreu, C. K., \& Weingart, L. R. (2003). Task versus relationship conflict, team performance, and team member satisfaction: a meta-analysis. Journal of Applied Psychology, 88(4), 741.

De Drue, C., \& Gelfand, M. (2008). Conflict in the Workplace: Sources, Functions, and Dynamics Across Multiple Levels of Analysis [in:] The Psychology of Conflict and Conflict Management in Organizations. NewYork. 
Gaumer Erickson, A. S., \& Noonan, P. M. (2018). Conflict management formative questionnaire. In The skills that matter: Teaching interpersonal and intrapersonal competencies in any classroom (pp. 183-184). CA Thousands Oaks.

Hackman, J. R. (1990). Groups that work and those that don't: Jossey-Bass.

Ilesanmi, A. (2017). Dynamics of Collective Bargaining in Resolving Conflict in Employment Relations. Indian Journal of Industrial Relations, $52(3)$.

Jaworski, B. J., \& Kohli, A. K. (1991). Supervisory feedback: Alternative types and their impact on salespeople's performance and satisfaction. Journal of Marketing Research, 28(2), 190-201.

Jehn, K. A., \& Mannix, E. A. (2001). The dynamic nature of conflict: A longitudinal study of intragroup conflict and group performance. Academy of Management Journal, 44(2), 238-251.

Lind, E. A., \& Tyler, T. R. (1988). The social psychology of procedural justice: Springer Science \& Business Media.

Luria, G., \& Yagil, D. (2008). Procedural justice, ethical climate and service outcomes in restaurants. International Journal of Hospitality Management, 27(2), 276-283.

Masterson, S. S., Lewis, K., Goldman, B. M., \& Taylor, M. S. (2000). Integrating justice and social exchange: The differing effects of fair procedures and treatment on work relationships. Academy of Management Journal, 43(4), 738-748.

Nur Shafini, M., Saidatul, F., Syahirah, A., Rapidah, O., Sakina, M., \& Khalid, A. (2016). The relationship between workplace conflict and job performance: A study of staff in terengganu higher learning institution. Journal of Applied Environmental and Biological Sciences, 6, 27-32.

Pasmore, W., Francis, C., Haldeman, J., \& Shani, A. (1982). Sociotechnical systems: A North American reflection on empirical studies of the seventies. Human Relations, 35(12), 1179-1204.

Pradhan, R. K., \& Jena, L. K. (2017). Employee performance at workplace: Conceptual model and empirical validation. Business Perspectives and Research, 5(1), 69-85.

Robbins, S. P., \& Judge, T. A. (2007). Organizational Behavior. New Jersey: Person Education. In: Inc.

Sheppard, B. H., Lewicki, R. J., \& Minton, J. W. (1992). Organizational justice: The search for fairness in the workplace: Lexington Books New York.

Simons, T., \& Roberson, Q. (2003). Why managers should care about fairness: the effects of aggregate justice perceptions on organizational outcomes. Journal of Applied Psychology, 88(3), 432.

Tjosvold, D. (2008). The conflict-positive organization: It depends upon us. Journal of Organizational Behavior: The International Journal of Industrial, Occupational and Organizational Psychology and Behavior, 29(1), 19-28.

Tyler, T. R., \& Blader, S. L. (2003). The group engagement model: Procedural justice, social identity, and cooperative behavior. Personality and Social Psychology Review, 7(4), 349-361.

Wageman, R. (1995). Interdependence and group effectiveness. Administrative science quarterly, 145-180.

Wiedower, K. A. (2002). A shared vision: The relationship of management communication and contingent reinforcement of the corporate vision with job performance, organizational commitment, and intent to leave.

Zapata-Phelan, C. P., Colquitt, J. A., Scott, B. A., \& Livingston, B. (2009). Procedural justice, interactional justice, and task performance: The mediating role of intrinsic motivation. Organizational Behavior and Human Decision Processes, 108(1), 93-105.

Zelenski, J. M., Murphy, S. A., \& Jenkins, D. A. (2008). The happy-productive worker thesis revisited. Journal of Happiness Studies, 9(4), 521-537. 